\title{
Literal Translation from English and Malay in the Written Communication among Malay Learners of French
}

\author{
Abdul Halim Hazlina ${ }^{1}$, Abdul Aziz Adi Yasran ${ }^{2}$, Mamat Roslina $^{1}$ \& Abdul Rahim Normaliza ${ }^{2}$ \\ ${ }^{1}$ Department of Foreign Languages, Faculty of Modern Languages and Communication, Universiti Putra \\ Malaysia, Serdang, Malaysia \\ ${ }^{2}$ Department of Malay Language, Faculty of Modern Languages and Communication, Universiti Putra Malaysia, \\ Serdang, Malaysia \\ Correspondence: Abdul Halim Hazlina, Department of Foreign Languages, Faculty of Modern Languages and \\ Communication, Universiti Putra Malaysia, Serdang, Malaysia. E-mail: drhazlinahalim@gmail.com; \\ hazlina_ah@upm.edu.my
}

Received: April 4, 2013 Accepted: May 14, 2013 Online Published: June 28, 2013

doi:10.5539/ass.v9n9p197

URL: http://dx.doi.org/10.5539/ass.v9n9p197

\begin{abstract}
This study intended to examine the use of literal translation from English and Malay language in the written communication. The objectives were to investigate the most present language used in the translation to French, the use of the literal translation (LT) of Malay and English in the written communication among across gender, and to determine at which sentence level (words, phrase or syntax) the translation was used by the learners. The research utilized qualitative and quantitative methods of data analysis. The study was conducted among Malay non-native speakers of French as a foreign language at Universiti Putra Malaysia. A total of 50 subjects took part in this study. The task was to complete a writing task of 150-200 words after 100 hours of French learning. The results indicated that Malay language played a more important part in the translation, where 163 elements of translation were found as opposed to 76 elements from English language. Among the translations produced by the learners, 57 items were in the word form, 77 items in the phrase form and 105 items in the sentence form. The results of this study could help in the teaching of French to Malay learners by making them aware of literal translation which already in their repertoire and by encouraging them to use the translation effectively.
\end{abstract}

Keywords: literal translation, Malay learners, French language learning, writing task

\section{Introduction and Review of Literature}

One of the most important accomplishments for the learners in learning a new language is for them to be able to communicate their thoughts in the target language orally and in written form (Hazlina Abdul Halim et al., 2009a). Hence, the ways learners' process new information and the kinds of strategies they employ to understand, learn or remember the information have been the major concern of the researchers dealing with the area of foreign language learning (Hismanoglu, 2000).

Past researches have indicated that speakers of foreign languages do not have the absolute mastery of the foreign language learnt, therefore there are a few strategies identified to be employed by them in their speaking and writing process. Language learning strategies are therefore used to facilitate learners to improve their awareness and understanding of a target language. Wenden \& Rubin (1987) defined them as any set of operations, steps, plans, routines used by the learner to facilitate the obtaining, storage, retrieval, and use of information. Since non-native speakers will then use the communicative strategies to:

"Compensate for breakdown in communication due to limiting conditions in actual communication (e.g., momentary inability to recall an idea or grammatical form) or to insufficient competence in one or more of the other areas of communicative competence; and (b) to enhance the effectiveness of communication..." (Canale, 1983: 11).

Dörnyei (1995) in his study discovered a focused communicative strategy instruction could contribute to the second language development. Dörnyei \& Scott's (1997) taxonomy separated communication strategies into twelve kinds and three basic categories, which is direct strategies, indirect strategies and interactional strategies. In one of their taxonomy of communication strategies, underlined the literal translation. 
According to Richards \& Schmidth (2002), literal translation (LT) strategies involve translating by taking "word-to-word" from the original phrase or sentence. For Dörnyei (1995), literal translation is the strategy in which learners translate a lexical item, an idiom, or a structure from their mother tongue to the second language. Larson (1984) defined LT as a translation that follows closely the form of the source language. Palumbo (2009) further explained by stating that "LT is a form of translation which gives priority to lexical correspondences and results in ungrammatical sentences". Palumbo (2009) added that LT could equally mean "a translation that is as close as possible to the original while still ensuring not the naturalness, but the third language grammatically."

Dörnyei (1995:57) further explained that literal translation is one of achievement or compensatory strategies, as the strategy itself offers alternative plans for the learners to convey their original communicative thoughts by manipulating the available language they know.

Hence, this study examined the literal translation from Malay and English in the written communication among Malay learners of French. The LT in this research was identified as any French word, phrase or sentence in the respondents' writing which was not similar nor used in the normal French word, phrase, sentence or sentence structure in French.

\section{Research Objectives}

The present study attempts to investigate the most present language used in the translation to French by Malay learners across gender. The study also tries to determine at which sentence level (words, phrase or syntax) the translation was formulated by the learners. Therefore, this study aimed to answer the following question:

1)Which language is the most dominantly used as a literal translation strategy among the Malay learners of French?

2)Is there any difference between the use of strategies among the male and female Malay learners of French?

3)In which level of the sentences literal translation strategies were used by Malay learners of French?

\section{Methodology}

This study utilized both quantitative and qualitative methods of data collection. The subjects were intermediate French language proficiency students at Universiti Putra Malaysia. A total of 50 Malays participated in this study. Subjects were 25 males and 25 females. The instrument used in the study was the questionnaire (demographic section) and the administration of the writing task by the subjects.

The writing task consisted of a short essay of 10 to 15 sentences in French on their normal routine festive seasons, namely Aidilfitri and Christmas. The subjects were not introduced to the essay prompt, but they were assumed to have sufficient vocabulary and grammar to develop the essay after their 100 hours of French lessons. The subjects were not allowed to erase their writings hence they would have to bar them and rewrite the correct answer on top of the mistakes. The objective was for the researcher to be able to identify any self correction strategies the subjects used in their writing. The analysis of the literal translation strategies for the writing task was adapted from Dörnyei (1995) definition in his communicative strategies taxonomy.

\section{Overall Findings}

In this study, the researcher found 239 element of LT. The repartition is as shown in Table 1.

Table 1. Overall use of literal translation strategies

\begin{tabular}{lcc}
\hline & Male students & Female students \\
\hline LT from English & 33 & 43 \\
LT from Malay & 87 & 76 \\
\hline
\end{tabular}

It was found that the male students were prone to use the LT from Malay (36\%) compared to female students. This was explained in the demographic section where the male students admitted to utilise Malay language more often in their formal and informal writings than female students. This figure was futher analysed and the results indicated the LT could be traced in word, phrase and sentence form. The results were indicated as below (Table 2). 
Table 2. Level of the LT utilized by the students

\begin{tabular}{lcccc}
\hline & \multicolumn{2}{c}{ Male students } & \multicolumn{2}{c}{ Female students } \\
\cline { 2 - 5 } & Malay & English & Malay & English \\
\hline LT from words & $22(25.3 \%)$ & $10(30.3 \%)$ & $14(18.4 \%)$ & $11(25.6 \%)$ \\
Lt from phrases & $24(27.6 \%)$ & $7(21.2 \%)$ & $29(38.2 \%)$ & $17(39.5 \%)$ \\
LT from sentences & $41(47.1 \%)$ & $16(48.5 \%)$ & $33(43.4 \%)$ & $15(34.9 \%)$ \\
TOTAL & $\mathbf{8 7}$ & $\mathbf{3 3}$ & $\mathbf{7 6}$ & $\mathbf{4 3}$ \\
\hline
\end{tabular}

It was found from Table 2 that Malay was a dominant language in the LT for both genders. Most of the LT was in the sentence form. Both genders utilised LT from Malay sentences the most, which accounted to $47.1 \%$ from the overall LT for male students and $43.4 \%$ for female students. The LT from Malay and English phrases were shown in the Table 3.

Table 3. LT from Malay and English phrases

\begin{tabular}{lcc}
\hline LT from English and Malay phrases & Male & Female \\
\hline LT from Malay expression & 18 & 14 \\
LT from English expression & 5 & 7 \\
LT from Malay prepositions and name of places & 2 & 5 \\
LT from English prepositions and name of places & 0 & 3 \\
LT from Malay adjectives & 1 & 3 \\
LT from English adjectives & 4 & 2 \\
LT from Malay possessive forms & 3 & 3 \\
LT from Malay possessive forms & 0 & 3 \\
LT from subject pronouns & 0 & 2 \\
Total & $\mathbf{3 3}$ & $\mathbf{4 2}$ \\
\hline
\end{tabular}

Table 3 above showed the LT from phrases, which in majority involved expression from Malay and English languages (69.7\% for male students and 50\% for female students). From this total, $54.5 \%$ involved LT from Malay language expressions by male students and $33.3 \%$ by female students. Again, the high percentage indicated that Malay was a dominant language for LT by Malay students. LT from Malay and English words includes word categories as follows:

Table 4. LT from Malay and English words

\begin{tabular}{lccc}
\hline LT from words & Male & Female & Total \\
\hline LT from Malay verbs & 10 & 4 & 20 \\
LT from English Verbs & 3 & 3 & 16 \\
LT from Malay nouns & 3 & 6 & 3 \\
LT from English nouns & 4 & 3 & 2 \\
LT from Malay subject pronouns & 2 & & 2 \\
LT from English subject pronouns & 1 & 1 & 5 \\
LT from Malay prepositions & & & \\
LT from English prepositions & 2 & 1 &
\end{tabular}


LT from Malay possessive

LT from English possessive

LT from Malay adverb

LT from English adverb

LT from Malay numeral form

LT from English numeral form

LT from Malay question form

LT from English question form

LT from Malay conjunction

LT from English conjunction

TOTAL
2

6

6

1

1

1

35
1

22

Table 4 indicated that the male students utilised the LT from Malay and English words (61.4\%) more frequently than female students $(38.6 \%)$. Out of the 57 words that were found to be literally translated, 37 words $(64.5 \%)$ were originated from Malay language. This figure was mainly contributed by Malay and English verbs (35\% from overall translated words) and Malay and English nouns (28.1\%).

Based on the results above, it can be concluded that Malay language played a more important role in the literal translation to French as compared to English language for Malay students learning French.

\subsection{LT from English}

\subsubsection{LT from Words in English}

The LT from English words resulted different meaning in French. In the example from Table 5, the verb visite was used in French for buildings, not for human beings. The verb habiller was actually a verb to express the action of dressing up someone and the word usure was used to say a worn or old clothes.

Table 5. LT from English verbs

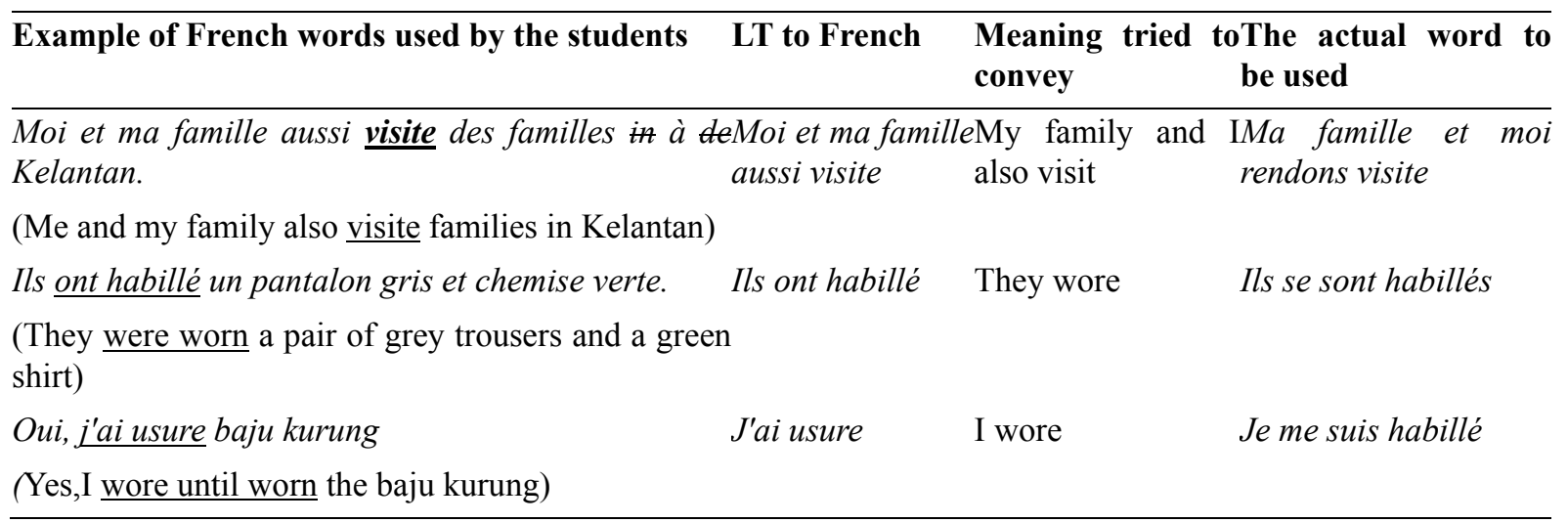

\subsubsection{LT from Phrases in English}

The LT from English phrases by the students on the other hand, contributed to the grammatical errors and incomprehensible phrases in French. Some of the examples are illustrated in Table 6. 
Table 6. LT from English phrases

\begin{tabular}{|c|c|c|}
\hline Phrases used by the students & Meaning tried to convey & The actual phrase in French \\
\hline $\begin{array}{l}\text { 1. Il est magnificent à ma. } \\
\text { (It is magnificent to my) }\end{array}$ & It is magnifiscent to me. & Pour moi, c'est magnifique \\
\hline $\begin{array}{l}\text { 2. Alors, sur que jour en general, on } \\
\text { s'habille «Baju kurung»pour la femme } \\
\text { et «Baju Melayu» pour le homme. } \\
\text { (So 0, we wear «Baju kurung» for the } \\
\text { women and «Baju Melayu» for the } \\
\text { men). }\end{array}$ & $\begin{array}{l}\text { So on that day we wear «Baju } \\
\text { kurung» for the women } \\
\text { and «Baju Melayu» for } \\
\text { the men }\end{array}$ & $\begin{array}{l}\text { Ce jour-là, on porte du "Baju } \\
\text { Kurung" pour les femmes et du } \\
\text { "Baju Melayu" pour les } \\
\text { hommes. }\end{array}$ \\
\hline $\begin{array}{l}\text { 3. Nous ne voulons pas parle quelque } \\
\text { unfortune words. Mon père donne moi } \\
\text { une rouge paquet. } \\
\text { (We don't want speak some } \\
\text { unfortunate words. My father gives } \\
\text { me a red packet.) }\end{array}$ & $\begin{array}{l}\text { We don't want to speak about } \\
\text { bad things. My father gives } \\
\text { me a red packet. }\end{array}$ & $\begin{array}{l}\text { Nous ne voulons pas parler du } \\
\text { mal. Mon père me donne un } \\
\text { paquet rouge. }\end{array}$ \\
\hline (): No equivalent translation & & \\
\hline
\end{tabular}

\subsubsection{LT from Sentences in English}

The LT from English language by the students were merely comprehensible (Sentence 1 and 2 from Table 7). The sentences were grammatically incorrect and not a sentence of French were correct. On the other hand, Sentence 3 and 4 were completely incomprehensible in French.

Table 7. LT from English sentences

\begin{tabular}{lll}
\hline Sentences by the students & Meaning tried to convey & The actual sentence in French \\
\hline Ce sont tous délicieux. Ce sont chauds & $\begin{array}{l}\text { They are all delicious. They are } \\
\text { spicy }\end{array}$ & $\begin{array}{l}\text { Ils sont tous délicieux. Ils sont } \\
\text { épicés. }\end{array}$ \\
Quelles places ton famillé habite? & $\begin{array}{l}\text { In which area your family } \\
\text { lives? }\end{array}$ & Ta famille habite où? \\
Nous sommes eu tout à Singapore & We were all in Singapore & $\begin{array}{l}\text { Nous étions tous à Singapour } \\
\text { Tel le chouette! }\end{array}$ \\
\hline
\end{tabular}

\subsection{LT from Malay}

\subsubsection{LT from Words in Malay}

LT from Malay words in majority involved Malay verbs, nouns and adverbs (29 words out of 37 found). For the LT from Malay verbs, it was found that there were two types of LT done by the subjects: LT from Malay to English to French and LT from Malay to French. The first type (Malay English French) involved the words mengunjungi and memakai in the past tense. 
Table 8. LT from verbs Malay - English - French

\begin{tabular}{lllll}
\hline $\begin{array}{l}\text { Example of } \begin{array}{c}\text { French } \\
\text { constructed by the students }\end{array} \\
\text { sentences }\end{array}$ & LT to French & $\begin{array}{l}\text { Meaning tried } \\
\text { to convey }\end{array}$ & $\begin{array}{l}\text { The actual word to } \\
\text { be used }\end{array}$ \\
\hline $\begin{array}{l}\text { Moi et ma famille aussi visite des familles } \\
\text { in à de Kelantan. }\end{array}$ & $\begin{array}{l}\text { Moi et ma famille } \\
\text { aussi visite }\end{array}$ & $\begin{array}{l}\text { My family and I } \\
\text { also visit }\end{array}$ & $\begin{array}{l}\text { Mamille et moi } \\
\text { rendons visite }\end{array}$
\end{tabular}

(Me and my family also visite families in Kelantan)

Ils ont habillé un pantalon gris et chemise

Ils ont habillé

They wore

Ils se sont habillés verte.

(They were worn a pair of grey trousers and a green shirt)

Oui, j'ai usure baju kurung

J'ai usure

I wore

Je me suis habillé

(Yes,I wore until worn the baju kurung)

The rest of the LT from verbs were from the second type. Some of the examples were as follows:

Table 9. LT from verbs Malay - French

\begin{tabular}{lllll}
\hline $\begin{array}{l}\text { Example of French sentences } \\
\text { constructed by the students }\end{array}$ & $\begin{array}{l}\text { LT to } \\
\text { French }\end{array}$ & $\begin{array}{l}\text { Meaning tried } \\
\text { to convey }\end{array}$ & Category & $\begin{array}{l}\text { The actual verb to } \\
\text { be used }\end{array}$ \\
\hline $\begin{array}{l}\text { Pourquoi tu sens tu es bruyant? } \\
\text { (Why you sense you are noisy?) }\end{array}$ & think & Verb verb & Pense que \\
A morning, nous prier et alors & prier & pray & Verb verb & Faisons la prière
\end{tabular}
manger.

(In the morning, we pray and eat )

Je grâce à mon parents aussi

grâce Ask for pardon noun Demande pardon

(I grace my parents too)

Ensuite, on feu le lemang cinq feu heures

(Then, we fire the lemang five hours)

The use of the LT on the nouns from Malay to French was resulted from the fact that the Malay vocabulary was a specific vocabulary that has an equivalent in French, or it was a symbolic name to Malaysian community which contains Malaysian culture.

Table 10. LT from nouns Malay- French

\begin{tabular}{llll}
\hline $\begin{array}{l}\text { Example of nouns used in the French } \\
\text { sentence }\end{array}$ & LT to French & $\begin{array}{l}\text { Meaning tried to } \\
\text { convey }\end{array}$ & The actual noun \\
\hline $\begin{array}{l}\text { Et dodol est les fruits cuit avec sucre rouge. } \\
\text { Maksud ayat: Dan dodol adalah buah yang } \\
\text { dimasak dengan gula warna merah }\end{array}$ & Sucre rouge & Palm sugar & Du sucre de palme \\
$\begin{array}{l}\text { Moi, on a un grand poulet Turquie, des } \\
\text { gâteaux et des desserts doux. }\end{array}$ & Poulet Turquie & Turkey & La dinde \\
$\begin{array}{l}\text { Maksud ayat: Kami ada satu ayam dari } \\
\text { Turki, kuih-muih dan manisan }\end{array}$ & & \\
$\begin{array}{l}\text { Je porte chemise Malais pour Hari raya. } \\
\begin{array}{l}\text { Maksud ayat: Saya pakai baju orang } \\
\text { Melayu untuk Hari Raya }\end{array}\end{array}$ & & \\
\hline
\end{tabular}




\subsubsection{LT from Malay Phrases}

The LT from Malay phrases was a part of the language phenomena called transitional competence or interlanguage, by Corder (1981). It was in fact a transitional situation in the acquisition of the targeted language, in this case French, where the students referred to their mother tongue to express an idea in the targeted language. In this research, such translation involved expression using French prepositions, adjectives and possessives.

Table 11. LT from Malay phrases

\begin{tabular}{|c|c|c|}
\hline Phrases used by the respondents & Meaning tried to convey & The actual phrase in French \\
\hline $\begin{array}{l}\text { 1. Je suis allé mon campagne pour } \\
\text { menyambut mon Hari Raya avec ma } \\
\text { famille. } \\
\text { (I went to the outskirt to celebrate my } \\
\text { Hari Raya with my family) }\end{array}$ & $\begin{array}{l}\text { I went to my hometown to } \\
\text { celebrate Hari Raya with my } \\
\text { family. }\end{array}$ & $\begin{array}{l}\text { Je suis allé chez des familles } \\
\text { pour célébrer l'Hari Raya avec } \\
\text { ma famille. }\end{array}$ \\
\hline $\begin{array}{l}\text { 2. Pendant Hari Raya, on va venir à la } \\
\text { village. } \\
\text { (During Hari Raya, we will come to } \\
\text { village). }\end{array}$ & $\begin{array}{l}\text { During Hari Raya, we went } \\
\text { back to our hometown. }\end{array}$ & $\begin{array}{l}\text { Pendant Hari Raya, on est allé } \\
\text { à notre ville natale.. }\end{array}$ \\
\hline
\end{tabular}

Some of the expressions were totally incomprehensible in French:

Table 12. LT from Malay phrases

\begin{tabular}{|c|c|c|}
\hline Phrases used by the respondents & Meaning tried to convey & The actual phrase in French \\
\hline 1. Le songkok, on porte en haut de la tête & $\begin{array}{l}\text { Songkok, we wear on top of } \\
\text { our head }\end{array}$ & $\begin{array}{l}\text { Le Songkok, on porte comme un } \\
\text { chapeau. }\end{array}$ \\
\hline $\begin{array}{l}\text { 2. Il est vers quatre heures et demie } \underline{a} \\
\text { partir } \underline{d^{\prime} i c i .}\end{array}$ & $\begin{array}{l}\text { It is around } 41 / 2 \text { hours from } \\
\text { here }\end{array}$ & $\begin{array}{l}\text { Il est environ quatre heures et } \\
\text { demie d'ici. }\end{array}$ \\
\hline
\end{tabular}

\subsubsection{LT from Sentences in Malay}

The LT from Malay sentences was mainly based on the oral discourse translated to French. The translation was detected in the sentences to indicate a place, sentences on one's costumes, habits, food and drinks, and exclamation. Table 13 showed some the translations by the students:

Table 13. LT from Malay sentences

\begin{tabular}{|c|c|c|}
\hline Sentences by the students & Meaning tried to convey & $\begin{array}{l}\text { The actual sentence in } \\
\text { French }\end{array}$ \\
\hline Nous allons beaucoup endroit & We go to lots of places & $\begin{array}{l}\text { Nous allons à beaucoup } \\
\text { d'endroits. }\end{array}$ \\
\hline $\begin{array}{l}\text { Cuisines traditionnelles fameux ici est } \\
\text { satay et nasi lemak. }\end{array}$ & $\begin{array}{l}\text { The traditional famous food } \\
\text { here is satay and nasi lemak }\end{array}$ & $\begin{array}{l}\text { Les cuisines traditionnelles } \\
\text { fameuses ici sont le Nasi lemak } \\
\text { et le satay }\end{array}$ \\
\hline Je suis mort si ne l'eau pas. & I am dead if I don't have water & $\begin{array}{l}\text { Je vais mourir s'il n'y a pas } \\
\text { d'eau }\end{array}$ \\
\hline
\end{tabular}

\section{Conclusion}

From the analysis, it was found that Malay language played an important role in the LT to French by the student, in the use of words, phrases and sentences. The use of the LT though ease the communication in French, 
rendered the sentence incomprehensible and grammatically incorrect. The results of this study were similar to the study by Hazlina Abdul Halim et al. (2009b), who investigated LT to French among Chinese and Indians.

This study implicates that though LT is one of the achievement strategies (Kongsom, 2009), the learners still have to be careful in using the strategy in order to turn it to their advantage. Thus, the instructors or the language teachers have a very important role in coaching and ensuring the implementation of the strategy in their foreign language teaching.

\section{Acknowledgement}

This research is funded by Universiti Putra Malaysia through the Research University Grant Scheme (RUGS) 2012.

\section{References}

Canale, M. (1983). From communicative competence to communicative language pedagogy. In J. C. Richards, \& R. W. Schmidt (Eds.), Language and communication (pp. 2-27). Harlow, UK: Longman.

Corder, S. P. (1981). Error analysis and interlanguage. Oxford: Oxford University Press.

Dörnyei, Z. (1995). On the teachability of communication strategies. TESOL Quarterly, 29(1), 55-85. http://dx.doi.org/10.2307/3587805

Dörnyei, Z., \& Scott, M. L. (1997). Communication strategies in a second language: Definitions and taxonomies. Language Learning, 47, 173-210. http://dx.doi.org/10.1111/0023-8333.51997005

Hazlina, A. H., Normaliza, A. R., Mohd Azidan, A. J., \& Adi Yasran, A. A. (2009a). The writing strategy in French language learning among Malaysian students: a qualitative approach. The International Journal of Learning, 16(5), 445-458.

Hazlina, A. H., Normaliza, A. R., Mohd Azidan, A. J., \& Adi Yasran, A. A. (2009b). Malaysian students' perceptions of the writing strategy in French language learning: a quantitative approach. The International Journal of the Humanities, 7(7), 85-96.

Hismanoglu, M. (2000). Language Learning Strategies in Foreign Language Learning and Teaching. The Internet TESL Journal, VI(8).

Kongsom, T. (2009). The effects of teaching communication strategies on Thai learners of English (Unpublished doctoral dissertation). University of Southampton, England.

Larson, M. L. (1984). Meaning-based translation: A guide to cross-language equivalence. Lanham, MD: University Press of America.

Palumbo, G. (2009). Key terms in translation studies. London: Continuum.

Richards, J. C., \& Schmidt, R. (2002). Longman dictionary of language teaching \& applied linguistics (3rd ed.). Harlow: Longman.

Wenden, A., \& Rubin, J. (1987). Learner Strategies in Language Learning. London: Prentice Hall International.

\section{Copyrights}

Copyright for this article is retained by the author(s), with first publication rights granted to the journal.

This is an open-access article distributed under the terms and conditions of the Creative Commons Attribution license (http://creativecommons.org/licenses/by/3.0/). 